"Developmental obstacles adversely affecting emerging contractors in the construction industry of Limpopo province"

AUTHORS

ARTICLE INFO

RELEASED ON

JOURNAL

FOUNDER
Zeleke Worku iD https://orcid.org/0000-0002-8808-3052

Zeleke Worku (2016). Developmental obstacles adversely affecting emerging contractors in the construction industry of Limpopo province. Problems and Perspectives in Management, 14(4-1), 170-180. doi:10.21511/ppm.14(41).2016.05 http://dx.doi.org/10.21511/ppm.14(4-1).2016.05

Friday, 23 December 2016

"Problems and Perspectives in Management"

LLC "Consulting Publishing Company "Business Perspectives"
NUMBER OF REFERENCES

0

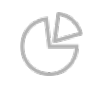

NUMBER OF FIGURES

0

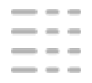

NUMBER OF TABLES

0

(C) The author(s) 2023. This publication is an open access article. 
Zeleke Worku (South Africa)

\title{
Developmental obstacles adversely affecting emerging contractors in the construction industry of Limpopo Province
}

\begin{abstract}
This study attempts to identify and quantify factors that adversely affect the growth and development of emerging contractors in the construction industry of Limpopo Province in South Africa. The study is based on a stratified random sample of 229 emerging contractors who operate in the construction industry of Limpopo Province. The degree of entrepreneurial skills in emerging contractors was assessed by using a composite index defined by Beck and DemirgucKunt (2012). Quantitative and qualitative research methods were used for data collection and analysis. The study found that 139 of the 229 emerging contractors selected for the study $(60.70 \%)$ lacked entrepreneurial skills by the standards of Beck and Demirguc-Kunt (2012), whereas 90 of them (40.18\%) had adequate entrepreneurial skills by the same standards. The study also showed that 141 of the 229 emerging contractors in the study $(61.57 \%)$ lacked basic skills in construction engineering. More than half of the contractors in the study had disadvantaged backgrounds in terms of technical and entrepreneurial skills as well as capital and access to finance. The study found that 122 of the 229 emerging contractors $(53.28 \%)$ were viable financially while the remaining 107 emerging contractors $(46.72 \%)$ were not viable financially. Results obtained from the study showed that viability in emerging contractors was significantly influenced by barriers such as lack of construction engineering skills, lack of entrepreneurial skills, lack of access to finance, inability to network with well-established contractors, inability to draw up business plans, and delay in payment for services rendered, in a decreasing order of strength.
\end{abstract}

Keywords: construction industry, emerging contractors, Limpopo Province.

JEL Classification: C5, M21.

\section{Introduction}

The study was conducted in order to identify and quantify key predictors of failure and underperformance among emerging contractors operating in the construction industry of Limpopo Province in South Africa. The study is based on data collected from a random sample of size 229 emerging contractors operating in the construction industry of Limpopo Province as an extension of the study conducted by Tshivhase and Worku (2012). According to reports issued by the Limpopo Business Support Agency (LIBSA, 2015), the failure rate among newly established emerging contractors in Limpopo Province is above 50\%. Similar reports have been published by the South African Construction Industry Development Board (CIDB, 2013, 2014, 2015). Reports published by the South African National Department of Public Works (2015) and Tshivhase \& Worku (2012) show that the key barriers to sustained growth and development among newly established construction firms in Limpopo Province are shortage of technical skills in construction engineering, shortage of capital and inability to network with well-established construction firms. A study conducted by the Limpopo Provincial Department of Trade and Industry (2014) shows more than half of newly established businesses in Limpopo Province are not viable financially mostly due to shortage of entrepreneurial skills and inability to render services

(C) Zeleke Worku, 2016.

Zeleke Worku, Ph.D., Professor, Business School, Tshwane University of Technology, South Africa. that are demanded in the local market. A report issued by the Limpopo Provincial Economic Development Enterprise (2015) indicates that nearly half of all start-up Small, Micro and Medium-sized Enterprises (SMMEs) in Limpopo Province fail before operating for three years or more due to shortage of mentoring, shortage of entrepreneurial skills, inability to network with potential clients, and lack of access to finance. The report shows that not enough assistance is provided to newly established businesses in all sectors of the economy. Annual reports issued by the Limpopo Provincial Department of Public Works $(2014,2015)$ show that newly established SMMEs in the construction industry of Limpopo Province are characterized by lack of technical skills in construction engineering, lack of finance and lack of basic entrepreneurial skills that are essential for networking and attracting clients.

Studies conducted by Ahlstrom \& Ding (2014), Baloyi \& Bekker (2011) and Bateman (2014) have shown that efforts made by the South African Government since April 1994 to improve the performance of emerging contractors in the construction industry of South Africa have not resulted in tangible results. According to Beck \& Demirguc-Kunt (2012) and Beetsma, Giuliodori, De Jong \& Widijanto (2013), emerging contractors lack technical and entrepreneurial skills as well as skills that are essential for networking with business partners and clients. Blaauw (2015) and Cassia \& Minola (2012) have pointed out that there is a significant association between poor quality of education and shortage of artisan skills in most developing nations 
of the world including South Africa. Based on a study conducted in Australia, Bourne \& Walker (2006) have shown that a sound educational system takes the practical needs of customers and stakeholders into account, and that educational systems used in most developing nations in Sub-Saharan African countries lack emphasis on practical and industrial expertise. Similar findings have been reported by Ugwu \& Haupt (2007), Lee, Hwang \& Choi (2012) and Yi (2013).

Studies conducted by Kassim (2011) and Kang \& Park (2009) have shown that it is beneficial to monitor and evaluate the performance of newly established and emerging contractors on a continuous basis as a means of ensuring the quality of service delivery in the construction industry. Jepsen \& Eskerod (2009) and Lin \& Germain (2003) have shown that competition with the private sector is essential for ensuring adequate performance in state owned enterprises. The study conducted by Hatmoko \& Scott (2010) has shown that supply chains in developing countries are often characterized by lack of respect for the fundamental principles of good governance, accountability and transparency, and that emerging contractors often struggle to secure contracts. El Asmar, Hanna \& Loh (2013) the quality of service delivery by emerging contractors in the construction industry is often poor, and that start-up businesses in the construction industry often struggle to compete with wellestablished contractors.

The degree to which emerging contractors in developing nations Such as South Africa are adversely affected by factors such as lack of technical, artisan and entrepreneurial skills has been pointed out by researchers such as Chan (2011), Chanut-Guieu \& Guieu (2014), Jensen (2010), Cho, Hong \& Hyun (2011) and Hajji \& Lewis (2013). In the Province of Limpopo, emerging contractors are required to be registered with the South African Construction Industry Development Board (CIDB) in order to compete for market opportunities and contracts. The study conducted by Tshivhase and Worku (2012) shows that emerging contractors in Limpopo Province are characterized by lack of artisan and engineering skills, lack of capital, inability to network with well-established construction firms and failure to penetrate the local market. Newly established construction firms in Limpopo Province are often placed at low grades of the CIDB. This fact makes it difficult for them to compete for large contracts. They often struggle to acquire practical skills by rendering services at the marketplace.

The study attempts to identify and quantify key obstacles to sustained growth and development in newly established construction companies in Limpopo Province based on data collected from a stratified random sample of size 219 emerging companies in the construction industry of Limpopo Province.

\section{Background}

Annual reports issued by the Limpopo Provincial Department of Public Works (2015), the Limpopo Provincial Department of Trade and Industry (2014), the Limpopo Provincial Economic Development Enterprise (2015) and the South African Construction Industry Development Board (CIDB, 2015) show that construction companies operated by emerging contractors in Limpopo Province are not competing favourably with well-established construction companies due to shortage of capacity, engineering-related skills, entrepreneurial skills and finance. According to Tshivhase and Worku (2012), emerging contractors in the construction industry of Limpopo Province need assistance in terms of skills and finance. There is a shortage of studies conducted in this area of study. The study aims to fill the gap by gathering data from emerging contractors operating in the five districts of Limpopo Province.

According to Blaauw (2015), Shin \& Yoon (2012) and Park, Kim, Lee \& Han (2011), newly established and emerging contractors in the construction industries of developing nations need mentoring, coaching and continuous support as a means of ensuring viability. The study by Santos \& Eisenhardt (2009) has shown that it is not possible to penetrate markets in the construction industry without having adequate skills, capital and access to clients. There is an acute shortage of studies conducted to identify and quantify key predictors of viability and performance in the construction industry of Limpopo Province. The study attempts to identify obstacles that are responsible for the high failure rate among newly established and emerging construction companies in Limpopo Province.

\section{Literature review}

Studies conducted by Price \& Newson (2003), Park \& Park (2012), Nemato \& Maritz (2007), Shen \& Liu (2003), Chin, Yoon, Choi \& Cho (2008), Duffy, Oberlender \& Jeong (2011) have shown that newly established construction companies need a combination of entrepreneurial and engineering skills in order to be profitable on a sustainable basis. According to Hyun, Hong, Ji, Yu \& An (2011) and Hwang, Park, Lee \& Kim (2010), a fragmented construction engineering sector requires policy intervention so that underprepared and under resourced construction companies can have access to local markets. In this regard, the study conducted by Tshivhase and Worku (2012) has shown that the construction industry of 
Limpopo Province is fragmented along racial lines drawn from old Apartheid legacies. According to Friedman, Chi \& Liu (2006), it is essential to provide a combination of technical and financial assistance as well as mentoring, monitoring and evaluation support programmes to start-up construction companies as a means of ensuring viability and long term survival. Ergen, Akinci, Fast \& Kirby (2007) have pointed out that it is prudent to provide mentoring and coaching services to start-up construction companies in order to promote the effective utilization of scarce resources and to enable newly established companies to exploit market opportunities. Masaaki, DunlapHinkler, Parente \& Mishra (2007) have pointed out that newly established construction companies benefit enormously from networking with wellestablished firms as a result of the transfer of practical skills in construction engineering and entrepreneurship. Milford, Hodgson, Chege \& Courtney (2012) have reported that newly established and emerging firms in the construction industry of Limpopo Province could benefit from mentoring, coaching, improved infrastructure and skills development programmes. The construction industry of Limpopo Province is deeply fragmented as a result of the legacies of apartheid. According to Milford, Hodgson, Chege \& Courtney (2012), training programmes in engineering and construction in the province are not tailor-made to the practical needs of emerging contractors. The current fragmentation of the emerging construction sector obstructs not only the growth of the industry, but also the development and economic growth of the country.

The study conducted by Milford, Hodgson, Chege \& Courtney (2012) has shown that poor entrepreneurial and engineering skills are key barriers to growth in start-up construction companies in Limpopo Province. The authors argue that the foremost reason of enterprise stagnation in Limpopo Province is attributed to the acute shortage of engineering skills, lack of access to finance and the absence of mentoring and coaching programmes. Start-up companies often do not have access to market opportunities due to their low CIDB grades and lack of capacity. Barriers such as lack of access to finance, poor technical skills, poor entrepreneurial skills, poor strategic planning and inability to network with wellestablished construction companies adversely affect growth and development in newly established construction companies. Cumbersome regulatory restrictions pose challenges to the development of SMMEs although structural reforms have achieved improvements. According to Statistics South Africa (2016), the construction industry of South Africa has made an average contribution of
$2.2 \%$ to the South African Gross Domestic Product (GDP) in the years between 2004 and 2013. However, the degree of support provided to the sector in the same period has been minimal. Although newly established and emerging construction companies were expected to grow their market share during the period 2004 and 2013, their market share has failed to grow mostly due to lack of capacity, lack of skills and difficulty in penetrating the local market. Cumbersome bureaucratic procedures and low CIDB grades have often frustrated and discouraged newly established and emerging contractors during the same period. In particular, no attempt has been made to transform the academic curriculum provided to trainees during the period.

Emerging contractors often fail to fulfil expectations of stakeholders due to lack of capacity, lack of technical skills and inability to complete projects according to approved time tables of actions. They are often characterized by inability to maintain service level agreements with clients due to lack of capacity and expertise. As a result, they are given low grades by the CIDB. This practice denies them the opportunity to compete with large construction firms in the local market. Experience from China, Japan and South Korea shows that emerging and newly established construction firms need a lot of support from the state as a means of creating a vibrant construction sector in Limpopo Province (Hyun, Hong, Ji, Yu \& An, 2011; Hwang, Park, Lee \& Kim, 2010). In order for the construction industry in Limpopo Province to be self-sustaining and viable, the state has a duty to create an economically enabling environment for new entrants into the construction industry of the province. Investments in construction drive the global economy and have become one of the yardsticks with which to measure the growth of Gross Domestic Products of countries. Stimulating activity in the construction sector encourages economic activities and employment multipliers. Hwang, Park, Lee \& Kim (2010) have reported that the construction industry creates more than half of total national capital investment in most countries. The authors have reported that Small, Micro and Medium-Sized Enterprises (SMMEs) in the construction industry are vital for creating jobs and livelihoods in all developing nations of the world including South Africa.

According to the CIDB (2013), South Africa has achieved substantial expansion in infrastructure investments in both the public and private sectors since April 1994. The CIDB (2013) has reported that the public sector accounts for about $65 \%$ to $70 \%$ of all investments made into the construction 
industry of South Africa in the years since 1994. Government spending on infrastructural development has created jobs in many parts of South Africa. National spending priorities include infrastructure to support industry development. These government infrastructure priorities have encouraged restructuring and downsizing of some established contractors and SMMEs that have come to participate progressively in South Africa economy and growth. Before 1994, collaboration between large and small enterprises was systematically discouraged due to Apartheid era policies.

Since 1994, various Contractor Development Programmes (CDPs) have been used by the Limpopo Provincial Government as a vehicle for producing skilled contractors in Limpopo Province. The key aspect of the programmes has been to enable new entrants to acquire labour-intensive construction techniques. In this programme, provincial departments and municipalities collaborate with the Construction Education Training Authority (CETA). In this arrangement, CETA provides funds and training opportunities to new entrants. The Expanded Public Works Programme (EPWP) has been used in order to generate labour-intensive jobs for the unemployed youth. In the drive to create labour intensive economic activities, various programmes and projects were established in various sectors of the economy such as infrastructure, economic, social and environment (Limpopo Provincial Department of Public Works, 2014). Increased capacity of Expanded Public Works Programme (EPWP) enabled the realization of economic impact consistent with government objectives. Further, toward this objective, the development programme for emerging contractors was bolstered with an intake of 500 youth for enrollment into the National Youth Service Programme (NYSP) in Limpopo Province. Five percent of the 500 youth were absorbed into the Limpopo Provincial Department of Public Works.

\section{Objective of study}

The key objective of study was to identify key barriers that adversely affect the development and growth of emerging contractors in the construction industry of Limpopo Province.

\section{Research questions}

The study had the following research questions:

- What factors affect viability in newly established or emerging construction companies operating in Limpopo Province?
- What factors affect the market share of newly established or emerging construction companies operating in Limpopo Province?

- How helpful is the Construction Industry Development Board in promoting emerging contractors in the Limpopo Province?

- How helpful are existing government policies in nurturing emerging contractors in the Limpopo Province?

\section{Methods and materials of study}

The design of the study was descriptive and crosssectional. Stratified random sampling was used for the selection of eligible respondents for the study. Data collection was done by using a structured, pre-tested and validated questionnaire of study and by conducting in-depth interviews with the key stakeholders in the construction industry of Limpopo Province. For each of the respondents who took part in the study, the degree of entrepreneurial skills was assessed by using a 5-point composite index introduced by Beck \& Demirguc-Kunt (2012). The viability of businesses was assessed by assessing profitability (Ahlstrom \& Ding, 2014). Quantitative data analysis was done by obtaining frequency tables and summary statistics, cross-tab analyzes (Hair, Black, Babin and Anderson, 2010), and binary logistic regression analysis (Hosmer \& Lemeshow, 2013). Cross-tab analyzes were used for identifying pairs of categorical variables that were associated with each other significantly. At the 5\% level of significance, the association between two categorical variables is said to be significant if the $P$-value is less than 0.05 . If the $P$-value is greater than or equal to 0.05 , the association is said to be insignificant at the same level. Logistic regression analysis was performed in order to identify influential barriers to development based on odds ratios. The statistical package STATA version 14 (STATA Corporation, 2015) was used for data capturing and analysis.

Table 2 shows the number of emerging contractors who took part in the study. The total number of contractors registered with the CIDB (2013) in Limpopo Province in 2013 was 1,268. Out of the 1,268 registered contractors, only 729 (57.49\%) were considered to be actively involved in construction work. Out of the 729 contractors, a stratified random sample of $n=229$ contractors $(31.41 \%)$ was selected for the study. In-depth interviews were conducted with 5 emerging contractors (one from each of the five districts of Limpopo Province). Saturation was reached at the end of five in-depth interviews (Ritchie, Lewis, Nicholls \& Ormstone, 2013). 
Table 1. CIDB grades of construction companies in Limpopo Province

\begin{tabular}{|c|c|c|c|c|c|c|c|}
\hline Grade & Civil & Electrical & Electronic & General building & Mechanical engineering & Specialized works & Total \\
\hline 2 & 150 & 22 & 12 & 193 & 21 & 33 & 431 \\
\hline 3 & 43 & 13 & 7 & 67 & 7 & 3 & 140 \\
\hline 4 & 104 & 19 & 19 & 96 & 4 & 4 & 246 \\
\hline 5 & 85 & 11 & 22 & 88 & 12 & 10 & 228 \\
\hline 6 & 76 & 6 & 5 & 76 & 5 & 0 & 168 \\
\hline 7 & 23 & 1 & 0 & 23 & 2 & 3 & 52 \\
\hline 8 & 2 & 0 & 0 & 0 & 0 & 0 & 2 \\
\hline 9 & 1 & 0 & 0 & 0 & 0 & 0 & 1 \\
\hline Total & 484 & 72 & 65 & 543 & 51 & 53 & 1.268 \\
\hline
\end{tabular}

Source: CIDB (2015).

The CIDB was established in Limpopo Province by the South African National and Provincial Departments of Public Works in 2010 in order to provide technical and administrative support to emerging contractors. The CIDB has so far provided support to 11,874 contractors

in areas related to contractor registration, technical advice and administrative support. Since 2010, the CIDB in Limpopo Province has provided assistance to 11,874 contractors out of which 10, $975(92.43 \%)$ were newly established contractors.

Table 1. Number of respondents selected for study

\begin{tabular}{|l|c|c|c|}
\hline \multicolumn{1}{|c|}{ District } & Number of contractors operating in Limpopo & Number of contractors selected into sample & Percentage (\%) \\
\hline Capricorn & 210 & 63 & $27.51 \%$ \\
\hline Vhembe & 154 & 51 & $22.27 \%$ \\
\hline Mopani & 126 & 44 & $19.21 \%$ \\
\hline Waterberg & 71 & 22 & $9.61 \%$ \\
\hline Sekhukhune & 168 & 49 & $21.40 \%$ \\
\hline Total & $N=729$ & $n=229$ & $31.41 \%$ \\
\hline
\end{tabular}

\section{Results of data analyzes}

Table 2 shows the general characteristics of the 229 emerging contractors who took part in the study. The table shows actual numbers of respondents out of 229 as well as percentages of attributes.

Table 2. Number of respondents selected for study

\begin{tabular}{|l|l|}
\hline \multicolumn{1}{|c|}{ Variable of study } & \multicolumn{1}{c|}{ Percentage } \\
\hline Viability of construction business & $\begin{array}{l}\text { Viable: } 122(53.28 \%) \\
\text { Not viable: } 107(46.72 \%)\end{array}$ \\
\hline \multirow{3}{*}{ CIDB grade } & Grade 2: $175(76.42 \%)$ \\
& Grade 3: $49(21.40 \%)$ \\
& Grade 4: $5(2.18 \%)$ \\
\hline \multirow{3}{*}{ Number of years of experience as } & Less than 2 years: $89(38.86 \%)$ \\
contractor & 2 to 5 years: $96(41.92 \%)$ \\
& 6 to 10 years: $29(12.66 \%)$ \\
& More than 10 years: $15(6.55 \%)$ \\
\hline \multirow{5}{*}{ Level of education } & Matric or less: $13(5.68 \%)$ \\
& Certificate: $19(8.30 \%)$ \\
& Diploma: $79(34.50 \%)$ \\
& Degree or higher: $118(51.53 \%)$ \\
\hline Ability to draw up business plans & Good: $16(6.99 \%)$ \\
& Above average: $33(14.41 \%)$ \\
& Average: $129(56.33 \%)$ \\
& Below average: $25(10.92 \%)$ \\
& Poor: $26(11.35 \%)$ \\
\hline \multirow{3}{*}{ Ability to perform auditing } & Good: $14(6.11 \%)$ \\
& Above average: $30(13.10 \%)$ \\
& Average: $134(58.52 \%)$ \\
& Below average: $24(10.48 \%)$ \\
& Poor: $27(11.79 \%)$ \\
\hline
\end{tabular}

\begin{tabular}{|c|c|}
\hline $\begin{array}{l}\text { At least one training assistance from } \\
\text { CIDB or related agencies received in } \\
\text { the past }\end{array}$ & $\begin{array}{l}\text { Yes: } 119(51.97 \%) \\
\text { No: } 110(48.03 \%)\end{array}$ \\
\hline $\begin{array}{l}\text { At least one financial assistance } \\
\text { from SEDA or related agencies } \\
\text { received in the past }\end{array}$ & $\begin{array}{l}\text { Yes: } 98(42.79 \%) \\
\text { No: } 131(57.21 \%)\end{array}$ \\
\hline $\begin{array}{l}\text { Experience of at least one delay in } \\
\text { payment }\end{array}$ & $\begin{array}{l}\text { Yes: } 148(64.63 \%) \\
\text { No: } 81(35.37 \%)\end{array}$ \\
\hline Initial capital in Rand & $\begin{array}{l}\text { 100, } 000 \text { Rand or less: } 27 \text { (11.79\%) } \\
101,000 \text { to } 200,000 \text { Rand: } 46 \\
(20.29 \%) \\
200,001 \text { to } 500,000 \text { Rand: } 139 \\
(60.70 \%) \\
500,001 \text { to } 1 \text { million Rand: } 13 \\
(5.68 \%) \\
\text { Above } 1 \text { million Rand: } 4(1.75 \%)\end{array}$ \\
\hline Current capital in Rand & $\begin{array}{l}\text { 100, } 000 \text { Rand or less: } 22(9.61 \%) \\
101,000 \text { to } 200,000 \text { Rand: } 43 \\
(18.78 \%) \\
200,001 \text { to } 500,000 \text { Rand: } 141 \\
(61.57 \%) \\
500,001 \text { to } 1 \text { million Rand: } 14 \\
(6.11 \%) \\
\text { Above } 1 \text { million Rand: } 9(3.93 \%) \\
\end{array}$ \\
\hline Source of initial capital & $\begin{array}{l}\text { Own money: } 53(23.14 \%) \\
\text { Family or friends: } 127(55.46 \%) \\
\text { Bank: } 49(21.40 \%)\end{array}$ \\
\hline $\begin{array}{l}\text { Experience of working with well- } \\
\text { established construction firms ever }\end{array}$ & $\begin{array}{l}\text { Yes: } 23(10.04 \%) \\
\text { No: } 206(89.96 \%) \\
\end{array}$ \\
\hline $\begin{array}{l}\text { Experience of severe financial } \\
\text { difficulty ever }\end{array}$ & $\begin{array}{l}\text { Yes: } 88(38.43 \%) \\
\text { No: } 141(61.57 \%) \\
\end{array}$ \\
\hline $\begin{array}{l}\text { Ownership of own construction } \\
\text { equipment }\end{array}$ & $\begin{array}{l}\text { Yes: } 117(51.09 \%) \\
\text { No: } 112(48.91 \%)\end{array}$ \\
\hline Entrepreneurial skills & $\begin{array}{l}\text { Good: } 28(12.23 \%) \\
\text { Above average: } 32(13.97 \%)\end{array}$ \\
\hline
\end{tabular}


Table 2 (cont.). Number of respondents selected for study

\begin{tabular}{|l|l|}
\hline \multicolumn{1}{|c|}{ Variable of study } & \multicolumn{1}{|c|}{ Percentage } \\
\hline \multirow{3}{*}{ Entrepreneurial skills } & Average: $121(52.84 \%)$ \\
& Below average: $29(12.66 \%)$ \\
& Poor: $19(8.30 \%)$ \\
\hline \multirow{5}{*}{$\begin{array}{l}\text { Degree of confidence in tender } \\
\text { procedures }\end{array}$} & Good: $21(9.17 \%)$ \\
& Above average: $16(6.99 \%)$ \\
& Average: $43(18.78 \%)$ \\
& Below average: $124(54.15 \%)$ \\
& Poor: $25(10.92 \%)$ \\
\hline \multirow{3}{*}{ Relevance of formal training to duty } & Good: $22(9.61 \%)$ \\
& Above average: $17(7.42 \%)$ \\
& Average: $45(19.65 \%)$ \\
& Below average: $122(53.28 \%)$ \\
& Poor: $23(10.04 \%)$ \\
\hline
\end{tabular}

\section{Results from cross-tab analyzes}

At the 5\% level, Table 4 shows the list of 10 significant associations that are obtained from Pearson's chi-square tests of associations on barriers to emerging contractors in Limpopo Province. These factors are lack of entrepreneurial skills, lack of access to finance, inability to network with well-established contractors, inability to draw up business plans, delay in payment for services rendered, lack of training assistance from the CIDB, stiff competition from large firms, lack of access to vital information on tender and lack of mentoring, in a decreasing order of strength.

Table 3. Barriers to viability in emerging construction companies

\begin{tabular}{|c|c|c|}
\hline Factors significantly associated with lack of viability in emerging construction companies & Observed chi-square value & P-value \\
\hline Lack of construction engineering skills & 19.8236 & 0.000 \\
\hline Lack of entrepreneurial skills & 18.1456 & 0.000 \\
\hline Lack of access to finance & 17.4326 & 0.000 \\
\hline Inability to network with well-established contractors & 16.5419 & 0.000 \\
\hline Inability to draw up business plans & 15.2948 & 0.000 \\
\hline Factors significantly associated with lack of viability in emerging construction companies & Observed chi-square value & $\mathrm{P}$-value \\
\hline Delay in payment for services rendered & 13.8239 & 0.000 \\
\hline Lack of training assistance from the CIDB & 11.2638 & 0.000 \\
\hline Stiff competition from large firms & 9.1659 & 0.000 \\
\hline Lack of access to vital information on tender & 8.4687 & 0.000 \\
\hline Lack of mentoring services to new contractors & 7.5569 & 0.000 \\
\hline
\end{tabular}

\section{Results from binary logistic regression analysis}

Table 5 shows odds ratios estimated from binary logistic regression analysis. At the 5\% level of significance, influential predictor variables of viability are characterized by odds ratios that are significantly different from 1, P-values that are smaller than 0.05 , and $95 \%$ confidence intervals of odds ratios that do not contain 1 .

Table 5. Factors that affect viability in emerging construction companies

\begin{tabular}{|c|c|c|c|}
\hline Barriers to viability in emerging construction companies & Odds ratio & P-value & $95 \%$ C.I. \\
\hline Lack of construction engineering skills & 8.45 & 0.000 & $(3.12,14.09)$ \\
\hline Lack of entrepreneurial skills & 7.98 & 0.001 & $(2.37,12.42)$ \\
\hline Lack of access to finance & 6.85 & 0.002 & $(2.19,10.55)$ \\
\hline Inability to network with well-established contractors & 5.88 & 0.006 & $(2.12,8.91)$ \\
\hline Inability to draw up business plans & 4.14 & 0.008 & $(1.69,7.66)$ \\
\hline Delay in payment for services rendered & 4.01 & 0.019 & $(1.47,7.54)$ \\
\hline
\end{tabular}

Table 5 shows that viability is significantly influenced by lack of construction engineering skills, lack of entrepreneurial skills, lack of access to finance, inability to network with well-established contractors, inability to draw up business plans, and delay in payment for services rendered, in a decreasing order of strength. The odds ratio of the variable lack of construction engineering skills is equal to 8.45. This indicates that an emerging contractor who lacks construction engineering skills is 8.45 times less viable in comparison with an emerging contractor who possesses adequate construction engineering skills. The remaining odds ratios could be interpreted similarly.

\section{Results from in-depth interviews}

In-depth interviews were conducted with 5 emerging contractors (one from each of the five districts of Limpopo Province). The following key findings were obtained from in-depth interviews:

\subsection{Unfair criteria used by the CIDB for grad-} ing contractors. In terms of CIDB requirements for upgrade, contractors are required to build a track record based on the number of projects completed, timeframes of such completions, and project grade. Three of the key requirements are works capability, financial capability and available capital. Work capability is measured as the number of successfully 
completed projects by a particular applicant. Financial capability considers annual turnover. Available capital looks at the net asset value of a company.

12.2. Unfair reasons used for downgrading emerging contractors. Most contractors who are downgraded could not meet requirements for retaining their CIDB grading due to a variety of factors. CIDB regulations require contractors to reapply every three years and an assessment is conducted as if contractors are registering for the first time. According to the CIDB, downgrading is deemed appropriate in cases when the contractor loses skills related capacity to perform work at the same level.

12.3. Unfair competition from well-established contractors. There are generally fewer projects that are advertised in public bulletins now compared to two or three years ago which has resulted in higher grade contractors competing with small contractors. Normally, it is emphasized that Grade 9 contractor looks upon lower grades projects to be unsustainable but due to rigorous competition, bigger contractors want small projects to preserve their workforce and sustain operations.

12.4. Poor culture of saving profit among emerging contractors. This challenge emerges when a profit has to be invested into the business, which competes with personal luxuries and self-interest owners wish to pursue. Attempts to address business development matters were reported and stakeholders in the industry talked to owners about their responsibilities to build and nurture their businesses. The importance of investing intensively on businesses is urged but the uptake of this advice is not tangible because there is no interest on the side of contractors. Four of the five respondents indicated that the temptation to use profit money was quite high among emerging contractors.

12.5. Shortage of adequately qualified construction engineers. The CIDB requires the contractors to appoint a professional when applying for Grade 7 or higher. Professions are needed to assist emerging contractors in attaining a threshold of quality standards because projects of Grade 7 or high are regarded as complex projects. While the regulation of professionals and their operations has a good intention, the scarcity of professionals in the country poses a real challenge. This lack of professions in the field of construction could deprive emerging contractors even those contractors having superior track record but struggling to secure a professional. However, it was commended that professionals may be the requirements when tendering projects especially if the client appreciated the complexities of a particular project and insisted the contractor to access professionals during implementation stage.
12.6. Backlog in infrastructural projects. There are exceptionally large inherited backlogs for infrastructure development, which are reflected by technical directors from both local and district municipalities. Ultimately, there is an urgent need to mobilize additional funds to address this deficit. Josie (2008) indicated that increasing infrastructure backlogs was an indication that current methods were not adequate for municipalities to deliver service. District municipalities were found to be more dependent on national government for funding while local municipalities which participated were more dependent on their own income, equitable share and Municipal Infrastructure Grant (MIG) funding from government. MIG funding provided by government to support municipalities has limitations to meet the demands for infrastructure. Further challenges to municipalities arose from the culture of non-payment of services within the municipalities. Eventually, funds generated to cater for infrastructure projects are never adequate to meet growing demand.

12.7. Shortage of funding for contractor development programmes. Contractor development programmes are provided by district municipality through funding from National Department of Public Works programme while interviewed local municipality does not have any leverage on the developmental programme or ownership. In the district municipality, for contractors to be selected into the programme, a registered certificate is a precondition and the process requires contractors to go through a learnership for about three years. As a result of limited funding, the programme was being implemented at a very limited scale with only three contractors finishing the programme in 2010.

12.8. Shortage of funding for low level construction projects. The respondents indicated that there was an acute shortage of low level construction projects that could be handled by emerging contractors due to lack of finance in the Province of Limpopo. Local municipalities in the province were generally poor with regards to funds for low level construction projects. As a result, emerging contractors had to compete with well-established firms for large construction projects. As a result of the lack of commitment displayed by emerging contractors, one of the municipalities interviewed reviewed policy of surety deduction for small, medium and large enterprises and mandated that only small projects were deducted for surety in the payment certificate. In this amendment, for all medium and larger-scale projects, contractors have to get surety guarantees to cover risks to clients. 


\section{Discussion of results}

The study has shown that 122 of the 229 emerging contractors $(53.28 \%)$ were viable financially while the remaining 107 emerging contractors $(46.72 \%)$ were not viable financially.

Results obtained from cross-tab analyzes have shown that viability in emerging contractors was significantly influenced by barriers such as lack of entrepreneurial skills, lack of access to finance, inability to network with well-established contractors, inability to draw up business plans, delay in payment for services rendered, lack of training assistance from the CIDB, stiff competition from large firms, lack of access to vital information on tender and lack of mentoring, in a decreasing order of strength.

Results obtained from binary logistic regression analysis have shown that viability among emerging contractors was significantly influenced by lack of construction engineering skills, lack of entrepreneurial skills, lack of access to finance, inability to network with well-established contractors, inability to draw up business plans, and delay in payment for services rendered, in a decreasing order of strength.

Lack of investment on contractor development programmes. One of the innovations to encourage employment creation has been the establishment of Contractor Development Programmes. However, such programmes have structural problems and have not been run efficiently to accommodate largenumber of emerging contractors in the Limpopo Province. The fact that the majority of small contractors are emerging on their own makes it difficult to overcome some challenges in the process.

Lack of practical assistance and mentoring programmes to emerging contractors. Because of the financial considerations of professionals in terms of remuneration and exposure to valuable experience, emerging contractors have had to contend with lack of suitably qualified professionals. During interviews, CIDB affiliate stated that it was a regulation of CIDB that contractors appointed a qualified professional when upgrading to Grade 7 or higher. This is because higher CIDB grades require advanced skills and necessitate best engineering practices. Currently, the shortage of professionals is a barrier particularly to contractor development as most professionals with superior proven track record do not find it attractive to work for emerging contractors.

Lack of investment in infrastructure development projects. The challenge confronting the construction industry is insufficient investments in infrastructural projects which largely depend on relative economic growth (Milford et al., 2002). This study has established the vulnerability of emerging contractors in the Limpopo Province, because they are primarily dependent on the availability of infrastructure budgets of municipalities. Compounding the problem further for emerging contractors is the reality of inefficient municipal administrative and management processes, which have rendered them prone to national government administration. While preference would be one in which there is budgetary realignment in municipal allocations, this remains an ideal. It was also important to note that in those municipalities that formed part of this study, there were widespread backlogs for projects that were supposed to be implemented. However, such projects remain pending with allocated funding not accounted for. This reality has contributed significantly to the growth of civil discontent in municipalities - arising from lack of progress and the improvement in people's lives.

Lack of transparency in tender procedures. Generally, there are challenges regarding tender transparency arising from inherent inconsistencies in the handling of relevant tender documentation. Further, the process is also prone to deliberate human irregularities to influence pre-determined outcomes. One's ability to influence tender outcomes is a valuable asset against which there is a premium. Inevitably, uncertainties over the outcomes of tender processes rank amongst the highest factors contributing to the dissatisfaction and despair of small contractors. The need for transparency in the tender adjudication process through the implementation of standard operating procedures, which are subject to scrutiny, would contribute significantly toward restoring the credibility of the process.

Failure to compete favourably with wellestablished construction companies. All five respondents who were interviewed indicated that emerging contractors were not adequately equipped to compete with well-established businesses, and that they needed tangible assistance from the South African Government as a means of building capacity for sustained development and growth. There were rivalries between emerging and wellestablished contractors. This could be as a result of the high number of emerging contractors chasing after a few number of construction projects. Employees of the CIDB indicated that there was a general trend of decline in the average number of projects advertised in the contemporary period compared to the past few years. Overall, this has led to established contractors competing with small contractors. This has disadvantaged small-scale emerging contractors due to intensified competition for small-scale projects. Thus, the sustainability of emerging contractors remains precarious under these circumstances. If this trend continues, many such 
contractors would eventually be marginalized out of business. Such an outcome would be very undesirable as it would directly undermine government intentions through Black Economic Empowerment. It would inadvertently undermine the determination to improve the skills of black contractors and maintain the current reality of skewed CIDB grading and ownership along racial lines.

\section{Recommendations}

Based on the findings of the study, the following feasible recommendations are made to the Limpopo Provincial Government:

The promotion of capacity building programes in Limpopo Province. This research has established that Limpopo has limited CDPs to develop and nurture emerging contractors to become autonomous independent sustainable entities. It is recommended that resources are allocated to CDPs to address constraints associated with such critical requests as project management, technical skills, contractual matters, business and financial management skills. Overall, there is an urgent need for support and guidance for the sustainability of emerging contractors.

Increasing funding for infrastructural projects in Limpopo Province. Emerging contractors are more dependent on municipalities for contracts followed by provincial departments. However, this reality is largely an inevitable outcome of insufficient funding, which has resulted in serious infrastructure backlogs. It is therefore recommended that government should inject more funds to municipalities, especially rural municipalities where there are large infrastructure backlogs. Overall, there is an urgent need to increase funding to provincial agencies in support of small business enterprises in the province.

More transparency in tender procedures in Limpopo Province. To restore confidence in the procedures and regulations governing tender processes, it is recommended that all provincial government in Limpopo adopt a standard tender process and procedure. This would greatly enhance opportunities for contractors to identify their capacities and minimize recurring risks of failures. It is also recommended that tender specifications should also inform contractors that they receive formal feedback about the reasons of their unsuccessful bids when requested in writing. For purposes of transparency, feedback should be provided at different stages of the application process.

Attracting more investments into Limpopo Province. With the knowledge that contractors renew their registrations with CIDB after three years, it is therefore recommended that emerging contractors should develop three-year invest plans for their businesses consistent with CIDB registration intervals. This should enable contractors to improve their capacity systematically and register for higher CIDB grades since their financial, project execution experience and available capital would have been improved.

Reviewing the policy on upgrading emerging contractors. It is important to state that CIDB has progressed well in promoting emerging contractors. However, the current requirements for upgrading are cumbersome, particularly for high grades. For instance, contractors are required to have professionals when registering for Grade 7 or higher. This requirement is perceived negatively as a barrier to emerging contractors in light of a shortage of professionals in the country for higher CIDB grades. It is therefore recommended that professionals should only be a requirement of registering for Grade 8 and 9 registrations since projects which fall in those grades are larger and very complex.

Injecting more capital into agencies that finance SMMEs. Analysis has established that emerging contractors fail to access finance and perform poorly on their projects due to lack of financial assistance. It is thus recommended that more funding should be injected into provincial agencies funding small contractors in the Limpopo Province.

Restricting entry into the Limpopo construction industry. The study has shown that Limpopo Province is home to a large number of emerging contractors who compete for a few number of market opportunities. As such, it would be helpful to restrict entry into the Limpopo construction industry as a means of protecting emerging contractors.

\section{References}

1. Ahlstrom, D. and Ding, Z. (2014). Entrepreneurship in China: An overview, International Small Business Journal, 32(6), pp. 610-618.

2. Baloyi, L and Bekker, M. (2011). Causes of Construction Cost and Time Overruns: The 2010 FIFA World Cup stadia in South Africa. Acta Structilia, 18(1), pp. 51-67.

3. Bateman, M. (2014). South Africa's Post-Apartheid Microcredit-Driven Calamity, Law, Democracy \& Development, 18(1), pp. 92-134.

4. Beck, T. and Demirguc-Kunt, A. (2012). Small and Medium-size Enterprises: Access to Finance as a Growth Constraint, Journal of Banking and Finance, 30(11), pp. 2931-2943. 
5. Beetsma, R., Giuliodori, M., De Jong, F., and Widijanto, D. (2013). Spread the News: the Impact of News on the European Sovereign Bond Markets during the Crisis, Journal of International Money and Finance, 34(1), pp. 83-101.

6. Blaauw, D. (2015). Sustainable Energy Solutions for Southern Africa: Powering Growth and Prosperity. Johannesburg: the Brenthurst Foundation.

7. Bourne, L. and Walker, D. (2006). Using a Visualizing Tool to Study Stakeholder Influence: Two Australian Examples, Project Management Journal, 37(1), pp. 5-21.

8. Cassia, L. and Minola, T. (2012). Hyper-growth of SMEs: toward a Reconciliation of Entrepreneurial Orientation and Strategic Resources, International Journal of Entrepreneurial Behavior \& Research, 18(2), pp. 179-197.

9. Chan, E.W.L. (2011). Action Research: the Use of Enterprise Resource Planning System in Construction Engineering and Project Management, Journal of Construction Engineering and Project Management, 1(3), pp. $19-27$.

10. Chanut-Guieu, C. and Guieu, G.C. (2014). High Growth Trajectories in Small and Medium Sized Enterprises: a Comparative Study, Journal of Small Business and Enterprise Development, 21(4), pp. 623-637.

11. Chin, S., Yoon, C., Choi, C., and Cho, C. (2008). RFID + 4D CAD for Progress Management of Structural Steel Works in High-Rise Buildings, Journal of Computing in Civil Engineering, 22(2), pp. 74-89.

12. Cho, K., Hong, T., and Hyun, C. (2011). Scheduling Model for Repetitive Construction Processes for High-Rise Buildings, Canadian Journal of Civil Engineering, 38(1), pp. 36-48.

13. Duffy, G.A., Oberlender, G.D., and Jeong, D.H.S. (2011). Linear Scheduling Model with Varying Production Rates, Journal of Construction Engineering and Management, 137(8), pp. 574-582.

14. El Asmar, M., Hanna, A., and Loh, W. (2013). Quantifying Performance for the Integrated Project Delivery System as Compared to Established Delivery Systems, Journal of Construction Engineering and Management, 139(11), pp. 40-53.

15. Ergen, E., Akinci, B., East, B. and Kirby, J. (2007). Tracking Components and Maintenance History within a Facility Utilizing Radio Frequency Identification Technology, Journal of Computing and Civil Engineering, 21(1), pp. 11-20.

16. Friedman, R., Chi, S. and Liu, L.A. (2006). An Expectancy Model of Chinese-American Differences in ConflictAvoiding, Journal of International Business Studies, 37(1), pp. 76-91.

17. Hair, J.F., Black, W.C., Babin, B.J., and Anderson, R.E. (2010). Multivariate Data Analysis: A Global Perspective, London: Pearson.

18. Hajji, A.M. and Lewis, M.P. (2013). Development of Productivity-based Estimating Tool for Fuel Use and Emissions from Earthwork Construction Activities, Journal of Construction Engineering and Project Management, 3(2), pp. 58-65.

19. Hatmoko, J.U.D. and Scott, S. (2010). Simulating the Impact of Supply Chain Management Practice on the Performance of Medium-Sized Building Projects, Construction Management and Economics, 28(1), pp. 35-49.

20. Hosmer, D.W. and Lemeshow, S. (2013). Applied Logistic Regression Analysis, New York: John Wiley and Sons.

21. Hyun, C.T., Hong, T.H., Ji, S.M., Yu, J.H. and An, S.B. (2011). The Development of Probabilistic Time and Cost Data: Focus on Field Conditions and Labor Productivity, Journal of Construction Engineering and Project Management, 1(1), pp. 37-43.

22. Hwang, S., Park, M., Lee, H. and Kim, H. (2010). A Dynamic Approach for Evaluating the Validity of Mortgage Lending Policies in Korean Housing Market, Korean Journal of Construction Engineering and Management, 11(5), pp. 32-40.

23. Jensen, M. (2010). Value Maximization, Stakeholder Theory, and the Corporate Objective Function, Journal of Applied Corporate Finance, 22(1), pp. 32-42.

24. Jepsen, L. and Eskerod, P. (2009). Stakeholder Analysis in Projects: Challenges in Using Current Guidelines in the Real World, International Journal of Project Management, 27(4), pp. 335-343.

25. Kang, J. and Park, H. (2009). Development of a Construction Performance Causal Map Using System Dynamics, Korea Institute of Building Construction, 9(2), pp. 63-68.

26. Kassim, N. (2011). ICT Implementation for Materials Management in Construction Projects: Case Studies, Journal of Construction Engineering and Project Management, 1(1), pp. 31-36.

27. Lee, S.M., Hwang, T. and Choi, D. (2012). Open Innovation in the Public Sector of Leading Countries, Management Decision, 50(1), pp. 147-162.

28. Limpopo Business Support Agency (LIBSA) (2015). Turning Business Ideas into Reality. Available at: http://www.libsa.co.za

29. Limpopo Provincial Department of Public Works (LPDPW). (2015). Annual Report for the Financial Year 2013/2014. Polokwane: Limpopo Provincial Department of Public Works.

30. Limpopo Provincial Department of Public Works (LPDPW). (2014). Annual Report for the Financial Year 2012/2013. Polokwane: Limpopo Provincial Department of Public Works.

31. Limpopo Provincial Department of Trade and Industry (2014). Annual Report for the Financial Year 2012/2013. Polokwane: Limpopo Provincial Department of Trade and Industry.

32. Limpopo Provincial Economic Development Enterprise (LPEDe). (2015). Annual report for the Financial Year 2013/2014. Polokwane: Limpopo Provincial Economic Development Enterprise. 
33. Lin, X. and Germain, R. (2003). Organizational Structure, Context, Customer Orientation, and Performance: Lessons from Chinese State-Owned Enterprises, Strategic Management Journal, 24(11), pp. 1131-1151.

34. Masaaki, K., Dunlap-Hinkler, D., Parente, R., and Mishra, H.A. (2007). Determinants of Cross-National knowledge transfer and its effect on firm innovation, Journal of International Business Studies, 38(2), pp. 259-282.

35. Milford, R.V., Hodgson, S., Chege, J. and Courtney, R. (2012). Construction Industry Development: The Need for Infrastructure Investment, Pretoria: Centre for Scientific and Industrial Research (CSIR).

36. Nemato, T. and Maritz, M.J. (2007). Evaluation of the Effect of Suretyship on Rapid Delivery Public Sector Construction Projects, Journal of the South Africa Institution of Civil Engineering, 49(1), pp. 10-15.

37. Park, M., Kim, W., Lee, H. and Han, S. (2011). Supply Chain Management Model for Ready Mixed Concrete, Automation in Construction, 20(1), pp. 44-55.

38. Park, Y. and Park, H. (2012). Development of Tunnel Construction Cost Model Using System Dynamics, Journal of the Digital Contents Society, 12(4), pp. 468-475.

39. Price, A.D. and Newson, E. (2003). Strategic Management: Consideration of Paradoxes, Processes, and Associated Concepts as Applied to Construction, Journal of Management in Engineering, 19(4), pp. 183-192.

40. Ritchie, J., Lewis, J., Nicholls, M.C. and Ormston, R. (2013). Qualitative Research Practice: A Guide for Social Science Students and Researchers, New York: SAGE.

41. Santos, F.M. and Eisenhardt, K.M. (2009). Constructing Markets and Shaping Boundaries: Entrepreneurial Power in Nascent Fields, Academy of Management Journal, 52(4), pp. 643-671.

42. Shen, Q. and Liu, G. (2003). Critical Success Factors for Value Management Studies in Construction, Journal of Construction Engineering and Management, 129(5), pp. 485-491.

43. Shin, T.H. and Yoon, S.C. (2012). A Construction Supply Chain Management Process with RFID/WSN-based Logistics Equipment, Journal of Construction Engineering and Project Management, 2(4), pp. 11-19.

44. South African Construction Industry Development Board (2013). Annual Report for the Financial Year 2011/2012. Pretoria: South African Construction Industry Development Board.

45. South African Construction Industry Development Board (2015). Annual Report for the Financial Year 2012/2013. Pretoria: South African Construction Industry Development Board.

46. South African Construction Industry Development Board (2015). Annual Report for the Financial Year 2013/2014. Pretoria: South African Construction Industry Development Board.

47. South African National Department of Public Works (2015). Annual Report for the Financial Year $2013 / 2014$. Pretoria: South African National Department of Public Works.

48. Stata Corporation (2015). User's Guide for STATA version 14. College Station: STATA Corporation.

49. Statistics South Africa (2015). Gross Domestic Product: Annual Estimates for 2004 to 2013. Available at: http://www.statssa.gov.za/.

50. Tshivhase, L. and Worku, Z. (2012). Barriers toward the Development of Emerging Contractors in the Limpopo Province, Journal of US-China Public Administration, 9(3), pp. 268-279.

51. Ugwu, O.O. and Haupt, T.C. (2007). Key Performance Indicators and Assessment Methods for Infrastructure Sustainability: a South African Construction Industry Perspective, Building and Environment, 42(2), pp. 665-680.

52. Yi, K.J. (2013). Modelling of On-Site Energy Consumption Profile in Construction Sites and a Case Study of Earth Moving, Journal of Construction Engineering and Project Management, 3(3), pp. 10-16. 